\title{
THE COMPARISON OF THE CONVENTIONAL DEVELOPMENT AND SUSTAINABLE DEVELOPMENT MODEL
}

\author{
Labović Bojan $^{1}$ \\ Vujović Dragan ${ }^{2}$ \\ Dašić Boban ${ }^{3}$
}

\begin{abstract}
Great ideas usually start out as rather simple ideas. In social sciences, the ideas which impact the lives of the millions and which direct policies must be available to all, not only to the elite. Only in this way can they properly permeate institutions from the global to the local level and become an integral part of human lives. The model of sustainable development challenges the conventional model of development. Namely, the conventional approaches simplify development by observing it as global modernization modeled after the example of industrialized, developed countries. Sustainability does not simply require balancing, i.e. compromising between inherently conflicting forces. It is rather a positive imperative which connects social, economic, and ecological benefits. Sustainable development advocates for the ethical position that the stock of natural resources must be preserved for the future generations and that the value of all
\end{abstract}

\footnotetext{
1 Kosovo and Metohija Academy of Applied Studies, Dositeja Obradovića 1, Leposavić, Serbia, e-mail: labovic.bojan@gmail.com

2 Faculty of Economics and Finance, University Union-Nikola Tesla, Cara Dušana 62-64, Belgrade, Serbia, e-mail: dragangagivujovic@gmail.com

${ }^{3}$ Faculty of Finance, Banking and Auditing, Alfa University, Palmira Toljatija 3, Belgrade, Serbia, e-mail: bobandasickg@gmail.com
} 
social benefits and costs, including the depletion of natural resources, must be included in accounting systems for the development performances to be properly measured. This paper covers a wide gap between the theoretical interpretation of sustainable development and the current situation in the world. The paper presents some critical views which perceive sustainable development as an illusion, but also gives arguments which claim that sustainable development has no alternative.

Keywords: ecosystem / sustainability / sustainable development / conventional model.

\section{INTRODUCTION}

Sustainability is a normative ethical principle for further development of society. It can vary regionally, nationally, or locally, to a greater or a lesser degree. The emergence of conflicts on different spatial and social scales is possible due to different ways of thinking and logic concerning sustainability. The last few decades have been marked by a radical shift in thinking. Today, energy and environmental issues are recognized as important challenges that we are striving to face more actively. Hence, there is a strong sentiment that "ordinary business" is no longer an option because the costs and risks of postponing suitable actions are constantly growing. Economic processes involved in decision-making have flaws. In many cases, they do not succeed in supporting the argumentation that would lead to the most suitable decisions. Many solutions proposed for energy, environmental issues and for enabling sustainability are opening up new unsolvable dilemmas. The concept of sustainable development has been presented as an option to overcome these problems since it makes it possible for businesses, companies, and state governments to redefine their policies.

This article aims at comparing the conventional model of development (focused on economic growth) and sustainable development (focused on broader interpretations of development with the imperatives being the viability and fairness of the global economy). The paper will present a critical review of the wide gap among the different theoretical interpretations of sustainable development to the current state of affairs in the world. The paper will include the critical observations that 
perceive sustainable development as a mere oxymoron or an illusion. However, it shall also discuss the arguments according to which sustainable development has no alternative since it stands for the protection of social benefits, the preservation of resources, continuous progress, and the creation of a better and more just world.

\section{Studies on the paradigm of sustainable development}

While specific analyses of any important topic are inevitably complex and subtle, the fundamental concepts which act as foundations of strong paradigms are relatively clear and easy to accept. The established paradigm of the concept of sustainable development stimulates governments to reevaluate and re-define their policies so that they could address a wide range of current development issues more efficiently. Sustainable development changes the perception of the future by influencing the decisions about process designs, product designs, and city configurations. In this sense, sustainable development offers both opportunities and challenges, but most importantly, it offers solutions (Roosa, 2008).

The report "Our Common Future" published by the World Commission on Environment and Development (WCED) in 1987, under the auspices of the United Nations, is seen as a starting point for the contemporary discussions on sustainable development. However, it is neither the starting point nor the potential endpoint for the evolution of the concept itself. After WCED report, the so-called Brundtland Commission Report, was published, the term sustainable development has been increasingly used in academic studies and the reports of numerous international agencies and governments. The notion of sustainable development has directed the implementation of environmental reforms within public and private organizations ever since and has affected the communication among the participants from the different social spheres (Bostrom, 2012). Over time, the proposed formulation of sustainable development has become the dominant notion about the relations between the environment and development, so today, it has an authoritative status as the guiding principle for achieving economic and social development.

The WCED report introduces the two key concepts that shall be briefly discussed here - the concept of "needs" and the concept of "constraints". 
The needs predominantly refer to the essential needs of the world's poor. Their needs must be given the highest priority. The constraints are the limitations found in the current technological conditions and the conditions of social organizations. As such, they impact the ability to meet both current and future needs.

The report introduced the new important component of intragenerational equality, as an addition to the concept of intergenerational equality (accomplished by minimizing harmful outcomes of human activities on the environment). Intragenerational equality refers to the equality within the present generation, while intergenerational equality refers to the equality between different generations. Namely, it had been previously assumed that environmental degradation would continue unless poverty and inequality in developing countries were urgently addressed. However, it is a widespread belief today that development policies should aim at ensuring the compatibility of intergenerational and intragenerational equality. This means that the protection of future generations through environmental policies must not be separated from the current needs of the poor (Murphy, 2012). Thus, the concept of sustainable development also contains an element of distributive ethics; it focuses on the distribution of benefits and burdens over time (between generations) and the distribution of benefits and burdens in space (within generations). In brief, sustainable development primarily aims at providing the conditions in which all people, both in poor and rich countries, and in present as well as in future, will be able to meet their basic needs. Besides, these goals must be achieved in a way that does not endanger the natural systems upon which life on the Earth depends. It is also crucial that the decision-making processes are democratic and legitimate.

Even though the provision of basic needs is a key element of sustainable development, this concept is quite diffusive and problematic. The wealthiest and the most influential social groups frequently impose the models and set the trends. These models become the ideals and desires that are for the wider global population, at least, hard to reach. As such, they are not supposed to be met in sustainable development. The basic human needs include: drinking water, food, clothes, accommodation, employment, energy, and hygiene. Life standards which surpass this minimum level are sustainable only if the given consumption standards 
are sustainable in the long-run. Meeting the basic needs, with the limitations imposed by the Earth's ecological carrying capacity, has two significant implications (Naess, 2001):

- First, to ensure that future generations will have a chance to fulfill their needs, current generations must reduce their current trends in environmental degradation significantly and limit their total consumption of non-renewable natural resources;

- Second, an increase in material consumption in developing countries (seen as inevitable in meeting the basic needs of the poor) must be accompanied by a reduction in material consumption in developed, industrialized countries, to keep the global environmental burden within sustainable limits.

In developing countries, sustainable development depends on the availability, accessibility, and quality of sustainable natural resources which are used to meet the basic needs of the people living in those countries. Sustainable development also depends on their political, institutional, and technical capacities to use their resources efficiently and organize the distribution of benefits justly among all the members of the present generation and the generations to follow. Developed countries can best contribute to these desired outcomes if they limit their own consumption and facilitate access to socially and ecologically beneficial technologies for developing countries. In most developing countries, the institutional inadequacy and inadequate government policies are important determinants of their inability to introduce and implement innovations to the extent that would be sufficient for achieving higher long-term growth rates. The structural economic dependency on natural resources is also an important factor in developing countries. Namely, their economies (especially those with low growth rates) are highly resource-dependent. First, they are highly dependent on the direct exploitation of the resources through primary industries like agriculture, forestry, and fishery. Moreover, their total export earnings predominantly stem from the exports of several primary products. These economies also tend to have high levels of debt and they undergo dramatic changes in land use; primarily in terms of converting forest areas into agricultural land and in terms of ever-increasing biodiversity degradation. 
The report also presents the concept of intrinsic values of the ecosystems. As opposed to instrumental values (i.e. the values that nature provides to people), there are also intrinsic values (i.e. the values of nature itself). According to this view, the preservation of the natural ecosystems should not only stem from the developmental goals. It should be the moral obligation of current generations towards the other living beings, as well as towards future generations (Naess, 2001). For many advocates of sustainable development, valuing nature and non-human life forms in an intrinsic way has also become an integral component of development. The scientific approaches in the field of ecosystem services have paid more attention to methods of monetary evaluation of ecosystems, as opposed to other evaluation methods. Here, the focus on instrumental values has been supplemented by the perspectives that emphasize the role of the intrinsic values. Thus, in the intrinsic sense, ecosystem values are not only seen as an instrument to achieve certain goals but are seen as a goal itself. Here this goal is not measured by monetary means but is rather represented as a moral duty. The instrumental-intrinsic dichotomy directs environmental decision-making in two ways: either through encouraging market-based approaches to nature preservation, such as payment for ecosystem services, or by promoting the preservation of protected areas without any human intervention.

An extended standpoint has also been proposed. In addition to acknowledging the values of nature itself (i.e. intrinsic values) and the values that nature provides to people (i.e. instrumental values), these new approaches also include preferences, principles, and virtues related to the relationship between man and nature (i.e. relational values). The concept of relational values (as a common framework for ideas researched in numerous disciplines and areas) provides a potential way to incorporate different perspectives found in social sciences into sustainability science and environmental decision-making processes. The evolution of this concept was guided by two adopted motivational forces: (1) interdisciplinary inclusion and (2) practical applicability. The first aims to provide a deeper and more comprehensive understanding of the relations between people and nature, by connecting the concepts through different intellectual traditions. The latter aims at assisting in the decision-making processes in real situations and at enabling the implementation of changes (Chan, 2018). 
There is no unique unanimous approach to sustainable development. Its absence results from the diversity of frameworks employed in different environmental protection programs, at different institutions, and in different communities operating at different spatial levels - from the global level to the local ones. The terminological issues might be also attributed to the dual nature of the concept itself. It encompasses development and sustainability which are both complex in their own right.

Sustainable development could be defined via the values that represent or support sustainable development. However, the values, as well as sustainable development, have multiple meanings. In general, the values are actually the beliefs about the values attributed to objects, qualities, or behaviors. They are typically expressed as good and acceptable or, conversely, bad and unacceptable. The values evoke feelings; they define us or guide us towards certain goals; they frame our attitudes and set standards based on which the behavior of an individual or a society can be judged upon. As such, the values often overlap with sustainability goals and sustainability indicators. Additionally, sustainable development could be defined through the practices. The practices involve numerous efforts in defining the concept, setting the goals, formulating indicators, and assigning values. The practices also include the development of social movements, organization of the institutions involved, proliferation of the science of sustainability and technology, and negotiations between (1) those who are primarily concerned with nature and the environment, (2) those who value economic development and (3) those who are committed to improving socio-cultural lifeconditions. These negotiations shall result in compromises that would be acceptable to all three sides. The inseparability of the natural environment and development, as described in Brundtland Commission Report, is the foundation of these compromises. Thus, a large part of what is described in the theory as sustainable development, are, in every-day practice, the negotiations which shall result in possible and feasible compromises between the economic, environmental, and social goals of different stakeholders. This is the main reason why numerous definitions of sustainable development emphasize the necessity of open and democratic decision-making processes (Kates, 2005).

The essence of Brundtland approach is a fair distribution of natural resources among different generations and within the current generation 
located at the different parts of the world, as well as finding a positive consensus between the ecological, social, and economic dimensions of the environment in ensuring safe living for all people and providing the adequate conditions for them to live and work in accordance with biophysical limitations of their natural surrounding. This is the primary goal of sustainability. For substantive and normative reasons, the relations between these three dimensions are generally seen as compatible and mutually supportive. For example, the UN Conference in Johannesburg that took place in 2002 further emphasized the need to integrate the three dimensions of sustainable development (Bostrom, 2012).

\section{Table 1. Main characteristics of the three aforementioned dimensions}

\begin{tabular}{|c|c|c|}
\hline Economic \\
dimension & $\begin{array}{c}\text { Economically sustainable system must be capable of producing } \\
\text { goods and services continually, must maintain the level of foreign } \\
\text { debt and avoid imbalances within the different sectors (since they } \\
\text { can be detrimental to agricultural and industrial production); }\end{array}$ \\
\hline $\begin{array}{c}\text { Ecologically sustainable systems must maintain stable stock of } \\
\text { natural resources by avoiding an excessive exploitation of } \\
\text { protection } \\
\text { dimension } \\
\text { renewable resources and draining non-renewable ones (should be } \\
\text { limited to the allowed extent by investing in adequate substitute } \\
\text { resources). This includes the preservation of biodiversity, } \\
\text { atmospheric stability, and other ecosystem functions that are not } \\
\text { classified as economic resources. Hence, from an ecological } \\
\text { perspective, the demand for resources must be limited while the } \\
\text { integrity of ecosystems and the diversity of species must be } \\
\text { maintained; }\end{array}$ \\
$\begin{array}{c}\text { Social } \\
\text { dimension }\end{array}$ & $\begin{array}{c}\text { A socially sustainable system must achieve distributive equity, } \\
\text { adequate access to social services, including health and education, } \\
\text { gender equality, and political accountability and participation. The } \\
\text { fulfillment of these basic needs, social justice, and participatory } \\
\text { democracy are the crucial elements of development and are } \\
\text { interrelated with environmental sustainability. }\end{array}$ \\
\hline
\end{tabular}

Source: Authors' work

These three dimensions of sustainability and their own complexities are clearly the sources of hardship in setting a precise and universal definition of sustainable development. The goals they present or imply are multidimensional. Thus, there remains a question of how to maintain their balance and how to evaluate success or failure. Also, the question is 
which goal should be given an advantage if the provision of necessary food and water supply requires changes in the use of land and thus causes the degradation of biodiversity?

The definition offered by the Brundtland Commission stands out as the most cited definition of sustainable development. According to this definition, sustainable development is a type of development that meets the needs of present generations without endangering future generations in meeting their own needs. However, there are hundreds of definitions of sustainable development. Most of them are sector-oriented (i.e. environmental, economic, civilizational) or formulated so that they emphasize managerial, technical, or philosophical/political decisions. However, we can extract and thus highlight their shared elements. Actually, there are four crucial characteristics of sustainable development that numerous different definitions and interpretations of the concept note (Martens, 2006). First, sustainable development is an intergenerational phenomenon, i.e. it is a process of transmission from one generation to the next one. In other words, for the reasonable evaluation of sustainable development, the temporal timeframe must include at least two generations (time range of 25 to 50 years). The second characteristic of sustainable development that is most frequently mentioned is its multilevel nature. Namely, sustainable development is a process occurring on several levels - the global level, regional level and local ones. Certain aspects that are sustainable on a national level may not be sustainable at the global level. The geographic incompatibilities occur as a result of the maneuvering mechanisms due to which the negative effects caused by one country or a region are transferred to other countries and regions. The third characteristic attributed to sustainable development in these definitions is that it covers multiple domains. Sustainable development comprises at least three domains: social, ecological, and economic. Even though sustainable development can be defined in terms of every separate domain, the true importance of the concept is in the mutual interrelatedness of these domains. One of the main goals of social development is to impact the development of justice, as well as life and medical conditions. In sustainable ecological development, the controlled usage and protection of natural systems are in the prime focus. In other words, the preservation of natural resources is of utmost importance. The most crucial goal of economic development 
is to enhance economic infrastructure and manage natural and social resources as efficiently as possible. The last shared element is the diversity of interpretations of sustainable development. Every definition requires the projections of both current and future social needs and the possible ways to accomplish them. However, such evaluations cannot be objective because they are inevitably uncertain.

A huge repertoire of definitions can be a source of confusion, but it also has certain benefits. Every attempt at defining this concept precisely, even if that would be possible, would have to be to some extent exclusive; at least some aspects would be left out. Consequently, every attempt at defining sustainable development is a crucial part of the continual dialogue that deepens our understanding of the concept and its importance. Moreover, sustainable development actually gains its resonance, power, and creativity from its vagueness and ambiguity (Kates, 2005). The open approach towards defining this concept enables communities and groups to identify the programs of sustainability that are suitable for their own conditions and circumstances. This variability and flexibility of the concept thus enables the active involvement of different subjects in the processes of sustainable development through their locally adapted solutions (Kemp, 2007).

\section{The characteristics of the conventional development model and the sustainable development model}

The paradigm of conventional development created the vision of a longterm global future since it was founded on the assumption that the values and the dynamics of an industrial system will be progressively implemented globally in an unlimited time span. This model was meant to maintain the continuity, the socio-economic arrangements, the values and lifestyles developed during the industrial era. The constellation of values that underpin this historical process, by analogy, provides the guiding principles that shape the vision of the conventional development which encompasses markets, investments, competition (seen as a major driver of economic growth and wealth allocation), free trade, and unlimited flows of capital and finance. These are supposed to accelerate globalization, industrialization, and urbanization, enhance products and labor markets, and support national countries and liberal democracies as appropriate forms of governance in the modern era. The paradigm of 
conventional development presupposes the continual developmental path of these mutually interrelated processes without greater social, technological, or ecological disturbances.

The critical approaches towards this western-centric development model are predominantly found in modern movements for environment protection (i.e. environmentalism movements). They have clearly indicated the flaws and failures of this model. Their arguments include the increase of unemployment in OECD countries, the difficult transitions of ex-communist countries, and the unsuccess of the development strategies employed in the third-world countries. The movement for environmental protection has raised a debate about several basic postulates of the Western development model. The most problematic issues that they brought to our attention include: (1) the use of nature and natural resources, (2) the true nature of progress, and (3) the western methods for managing societies, including the traditional patterns of authority within societies, as well as the methods used in decision-making and the implementations of public policies. Several arguments against this model of development shall be elaborated here.

First, the Western model has a limited understanding of the concept of progress, especially in terms of increased dominance over the natural surrounding and the usage of natural resources only to achieve certain benefits. For instance, the conversion of forested areas into the areas used for agricultural production would be seen here as an instance of progress. The alike actions attribute only the instrumental value to nature, while its intrinsic values are being completely ignored. Treating nature in this strictly instrumental way leads to absolute neglect of other non-human species and forms of life.

Second, the Western model gives the predominant role to economic growth even though this growth stimulates the increases in consumption. The increase in consumption has two major implications.

Consumerism deepens the inequity on both inter-and intra-generational level. First, it jeopardizes the current stock of natural resources that is supposed to be used as a basis for future development. It even accepts the ecological deterioration as an inevitable outcome of the progress (Baker, 2006). However, the assumptions that future generations will be facing 
serious ecological risks are quite realistic. These risks will most probably emerge from the climate changes that are currently taking place due to economic growth and are expected to even worsen in the future. This issue represents a tremendous difficulty in ensuring intergenerational equality. The potential proper response to these problems could be to reinforce and support the reduction of consumption, rather than to support the application of the technological solutions that should reduce the emissions of $\mathrm{CO} 2$ and other greenhouse gasses. In terms of intragenerational inequity, we must note that economically undeveloped countries and developing countries are affected by climate changes the most. This occurs partly due to their geographic positions and partly due to their limited capabilities and resources for facilitating the negative effects. In other words, their ability to implement the suitable strategies for diminishing these negative impacts are extremely limited. Ironically enough, poorer countries are harmed the most by the climate changes, even though their contribution to those changes is smaller in comparison to developed countries. Pollution is thus unjustly distributed at the global level. The combination of the demand for certain goods in the north and the poverty in the south has a significant impact on the developing countries in that they avoid strict ecological measures to ensure their own economic survival. There is compelling evidence that rich countries relocate their industries into poorer countries where certain practices of pollution are being tolerated. This asymmetry creates the so-called "pollution export" to poor countries. In this context, the proper response would be to suppress suchlike practices (Murphy, 2012). In addition, developed countries have based their development (and they still keep doing it) on the exploitation of their own natural resources, but also on the exploitation of the natural resources of the third-world countries (including the exploitation of people). According to the environmental movement, developed countries have actually propagated that suchlike practices will alleviate poverty. The reality is that these environmentally destructive development models have contributed to the poverty of the third-world countries.

According to the Western model, consumption contributes the most to human well-being. Namely, the common practice is to measure wellbeing by evaluating living standards, i.e. the amount of disposable income that individuals use to purchase goods and services. However, this development model that strengthens individual consumption rather 
than social cohesion leads to growing inequality, especially in the economic systems which are prone to cyclical recessions. While the Western model of development favors individual self-achievement at the expense of the common good, the environmental movement advocates for the "quality of life" to be placed first, instead of "standard of living". Life quality is rather observable on collective levels than on individual ones. The quality of life focuses on increasing the quality of the public domain by providing public education, medical care, and environmental protection, while the Western model ignores the fact that social stability also depends on the preservation of natural resources. Namely, the disturbances in the natural environment cause social disturbances and endanger human health. For example, the loss of wild biodiversity in agricultural systems increases the vulnerability of local communities, especially in terms of food supply. This in turn causes social unrests that can disrupt social and political institutions. Also, it is not possible to make a global replica of resource-intensive Western economies since their lifestyles are based on wealth and high levels of consumption. The Earth's ecosystem is unable to absorb the resulting pollution, and there are not enough natural resources (including water) to support suchlike developments. In other words, the model of development of the western industrialized countries cannot be implemented globally in the future, neither in its current form nor in its current dynamics.

The next argument against the western model is tightly related to the previous one. This argument emphasizes the fact that this model does not recognize the ultimate limits of economic growth which do exist. The utmost limits for further growth are imposed by the planet's saturation levels. The biosphere has limited potentials for absorbing the effects of human activities, and the natural resources of water, ores, and minerals are also limited. We still cannot overcome these limitations despite all the advances in modern technology oriented towards more efficient consumption of resources and faciliting the negative impacts on the environment (Baker, 2006).

The main differences between the conventional model of development and sustainable development are found in certain development policies and the essential understanding of development goals. The paradigm of conventional development proposes a model which is based on economic growth, while the paradigm of sustainable development focuses on the 
globally sustainable and equitable economies and societies (Labadi, Logan, 2016). Sustainable development views the stocks of natural resources as a primary constraint on production, while the conventional model emphasizes that the availability of capital is the primary constraint. Further on, sustainable development takes the ethical position that the stock of natural resources must be preserved for future generations and that the value of all social benefits and costs, including the depletion of natural resources, must be included in an accounting system for development performances to be measured. However, there are some shared beliefs. For instance, the conventional development policy and the policy of sustainable development both support investments into human capital seeing it as a valuable contribution in increasing productivity and social well-being. Both models reject fiscal deficits and excessive monetary expansion which lead to inflations. Also, the shared practice is to promote the research and technological development that would target the issues of energy consumption in industry and agriculture (Mikesell, 1992). Finally, we could say that sustainable development does not replace the previous models of development. It revises them fundamentally. It can be roughly presented as: conventional model of development + protection and preservation of the environment (Gudmundsson, 2016).

\section{The acceptance of the model of sustainable development}

In the previous period, significant academic efforts have been made to translate the political ideal of sustainable development into a more rigorous theoretical concept. The most adequate point of view is to observe sustainable development as the last evolutive stage of our understanding of the concept of human development.

Sustainable development builds on two other key concepts - economic growth and economic development. Growth is not synonymous with development. Growth is a quantitative increase, while development is a qualitative change. Growth is increasing in size by assimilating resources, while development is moving to the next, better state. Just as the concept of economic development was introduced to overcome the constraints of economic growth, the emergence of sustainable development reflects 
similar frustrations with the conventional concept of economic development. In this sense, it is necessary to explain the origin and definitions of both concepts (Purvis, Grainger, 2013):

- Economic growth

Economic growth is an increase in the output of goods and services in the economy and the total amount of income that is generated. It is measured with the index of real gross domestic product. This approach is given priority in a large number of governments. However, for many years, members of the environmental movement have been protesting against it. They believe that economic growth is destroying the natural environment and depleting natural resources because it gives priority to revenuegenerating consumption. Maximizing consumption means using the Earth's resources. The processes through which these resources are obtained and transformed into commercial products, create pollution and other forms of environmental degradation. Politicians are to some extent forced to continue to proclaim the value of economic growth due to the almost universal appeal that there is a possibility of generating higher incomes.

\section{- Economic development}

As revenue growth, observed independently, cannot guarantee that the full range of human needs and aspirations will be met, it was necessary to introduce a more comprehensive concept. Economic development can be defined as increasing and improving the wellbeing of a society as a whole. It manifests as the expanded set of opportunities available to a current generation. This implies not only income growth, but also the fairest possible distribution of income among populations that shall increase welfare throughout society (e.g. by increasing access to food, drinking water, housing, and better standards in health and education). Economic development thus leads to greater intragenerational equality. However, it does not specify the degree of equality that a country needs to achieve to be considered developed.

The usage of the term "development" instead of the term "economic growth" results from the fact that many measures of economic growth 
(as gross domestic product) are now seen as deficient when it comes to evaluating a national well-being. Instead, development encompasses a wider set of indicators of life quality, like educational level, access to basic freedoms, spiritual well-being, etc. Which components constitute development depends on the social goals set by governments, development agencies, etc. Development can include a list of attributes that any society strives to achieve and maximize. It may include: an increase in real per capita income, improvements in health and nutrition status, achievements in education, access to resources, "fairer" distribution of income, increasing basic freedoms.

The inclusion of sustainability indicates that certain political efforts must be made for development accomplishments to be preserved in the future. In that sense, it is necessary to elaborate at least minimal conditions for development to be sustainable. These conditions stem from the basic demand that the supplies of natural capital should not be reduced over time, i.e. they follow from the imperative that the stocks of natural capital must be continually preserved. More strictly speaking, there is an ultimate demand for the non-negative changes in supplies of natural capital and environmental quality. This means that the environment should not be degraded any further, while all improvements are more than desirable.

The estimations about sustainable development of any country must be made by taking into consideration the quality of long-term developmental path - with consistent rates of improvement, and not with short-term leaps in economic growth. Sustainable economic growth means that real gross national per capita income increases through time without hazardous biophysical effects (pollution, degradation of resources) or any negative social effects.

Sustainable development and economic growth differ in one more important aspect. Namely, for any specific territory to develop sustainably, its developmental path must be ideal. Taking into consideration the human tendencies towards uneven development and ecological degradation, this appears to be practically impossible. The processes of economic development can be achieved with different rates in numerous countries. On the other hand, the process described for sustainable development represents a theoretical ideal that practically 
cannot be reached in the foreseeable future. However, countries can still put an effort to "move” their current developmental paths as close to this ideal as possible, and thus increase the level of their developmental sustainability (Purvis, Grainger, 2013).

Focusing on sustainability means being more considerate about the future residents of the planet in comparison to the previous models. Namely, it would not be an exaggeration to claim that previous models assumed that "the future will take care of itself". The sustainable development approach unequivocally indicates that future prospects can be seriously impaired by activities taking place today. This does not mean that sustainable development gives more importance to the future than other development approaches. It simply emphasizes the inaccuracy of the assumption that future generations will be able to make free choices like current generations.

Pessimists tend to highlight that the concept of sustainable development is so flexible that it means many different things to many different people and does not require commitment to any specific policy. By setting goals far into the future, it may seem that even conflicting interests are approaching and coming closer along the parallel lines. Both the World Bank and radical environmentalists believe in sustainability and the proponents of the pessimistic perspective believe that any concept that is fully approved and accepted by all parties must certainly circumvent the essence of the problem. However, it is not easy to distance oneself from sustainable development because any argumentation against it is directly linked to an image of a greedy, myopic industrialist. Second, the rejection of sustainability might be interpreted as an acceptance of unsustainability. Who would dare to sketch that future? Ironically, an unsustainable scenario would be the easiest concept for defining; it is simply the exploitation of our current lifestyle (Campbell, 2013).

The gap between the theoretical interpretations of sustainable development and the current state of affairs in the world is still tremendously wide. The stock of natural resources is exploited irrationally, the greenhouse gas emissions are excessive, and there is a ever-growing pressure on the environment due to the expansion and globalization of societies, economies, and industries. These practices have lead and they still continue to lead development in those directions that 
can hardly be described as sustainable. As a result, some have taken a stance that practical reaches of sustainable development are disappointing and that sustainable development is just an oxymoron or illusion. However, the genius of this concept manifests in the acknowledgment that our battles against poverty (not only economic) and our battles for environment protection (not only biophysical) are tightly interrelated initiatives; both can fail if not treated simultaneously (Gibson, 2006).

When the key conditions for achieving sustainable development are observed, it is necessary to take into account the institutional requirements for the implementation of sustainable development policies. There is even a need for some systematic changes in social values. The World Commission on Environment and Development (WCED) advocates for a general transformation of policy and law based on the concept of sustainable development, emphasizing that the essential needs of a large number of people in less developed and underdeveloped countries are not adequately fulfilled. In the report of this Commission, sustainable development is explained as a process of change in which the exploitation of resources, investment directions, orientations of technological development, and institutional changes are in harmony with each other and they strengthen current and future potentials for human needs and aspirations. As an important global policy that cannot be ignored, sustainable development is included in several international non-binding documents such as: the G7 Declaration of the Paris Summit, the Hague Declaration on the Environment, the Bergen Declaration of the United Nations Economic Commission for Europe, and the Agreement on the European Bank for Reconstruction and Development. Simultaneously, the concept has been accepted in national and regional laws and conventions (Voigt, 2009).

\section{CONCLUSION}

There is a close connection between social, economic, and ecological systems. People depend on ecosystems in terms of health and safety. They can also transform ecosystems to obtain more or less desirable conditions. However, human action can also jeopardize or even disable the potentials of ecosystems to provide vital services. The consequences for human health and safety in those conditions can be dramatic or even 
fatal. The negative effects can cause a loss of resilience that plays an essential role in the prosperity of society. Numerous case studies have confirmed a strong link between resilience, diversity, and the sustainability of socio-ecological systems. Socio-ecological systems with a higher degree of resilience can absorb larger shocks without major changes.

For developing countries, sustainable development means an adequate influx of technology, knowledge, and material capital for creating higher living standards, while still maintaining the natural capital at more or less intact levels. On the other hand, excessive consumption in developed countries leads to irreparable damage to the global environment. However, the levels of environmental quality in these countries are seen as stable. Evidence suggests that the effects of pollution and climate changes are felt more in the poor regions because they live in riskier areas and have fewer resources to cope with adverse environmental events, due to their significantly lower levels of insurance. People with lower income spend higher shares of that income on energy. They use fuels such as coal and oil and are thus subjected to fiscal measures used to combate climate changes, such as the taxes on the use of fossil fuels. Thus, it is the developed countries that must drastically reduce their environmental pressures, regardless of which ways are chosen to achieve that goal.

The idea of conventional development is modelled on a straight-line progression from traditional to modern mass consumption society. In this setting, the tensions have developed between the promotion of economic growth and the equitable distribution of the basic needs. Development has remained unfair and has had tremendous negative environmental impacts. Although the preservation of natural capital is essential for sustainable economic production and intergenerational equality, market mechanisms do not function effectively to preserve natural capital. They even tend to diminish and degrade it. The concept of sustainable development must mitigate social injustices and environmental damage while maintaining a healthy economic base. 


\section{REFERENCES}

1. Baker, S. (2006), Sustainable Development, Routledge.

2. Bostrom, M. (2012), A Missing Pillar? Challenges in Theorizing and Practicing Social Sustainability: Introduction to the Special Issue, Sustainability: Science, Practice and Policy, 8(1), 3-14.

3. Chan, Kai M.A., Gould R.K., Pascual, U. (2018), Editorial Overview: Relational Values: What are They, and What's the Fuss About? Current Opinion in Environmental Sustainability, 35, A1-A7.

4. Gudmundsson, H., Hall, R.P., Marsden, G., Zietsman, J. (2016), Sustainable Transportation: Indicators, Frameworks, and Performance management, Springer.

5. Kates, R.W., Parris, T., Leiserowitz, A. (2005), What is Sustainable Development? Goals, Indicators, Values and Practice, Environment, 47, 8-21.

6. Kemp, R., Martens, P. (2007), Sustainable Development: How to Manage Something That is Subjective and Never Can be Achieved? Sustainability: Science, Practice and Policy, 3(2), 5-14.

7. Labadi, S., Logan, W. (2016), Urban Heritage, Development and Sustainability: International Frameworks, National and Local Governance, Routledge.

8. Martens, P. (2006), Sustainability: science or fiction? Sustainability: Science, Practice and Policy, 2(1), 36-41.

9. Murphy, K. (2012), The Social Pillar of Sustainable Development: A Literature Review and Framework for Policy Analysis, Sustainability: Science, Practice and Policy, 8(1), 15-29.

10. Naess, P. (2001), Urban Planning and Sustainable Development, European Planning Studies, 9 (4), 503- 524.

11. Purvis, M., Grainger, A. (2013), Exploring Sustainable Development: Geographical Perspectives, Earthscan Publications Limited, New York.

12. Roosa, S.A. (2008), Sustainable Development Handbook, The Fairmont Press, Inc., USA.

13. Voigt, C. (2009), Sustainable Development as a Principle of International Law: Resolving Conflicts Between Climate Measures and WTO Law, Martinus Nijhoff Publishers. 


\title{
KOMPARACIJA KONVENCIONALNOG MODELA RAZVOJA I ODRŽIVOG RAZVOJA
}

\author{
Labović Bojan \\ Vujović Dragan \\ Dašić Boban
}

Sažetak: Velike ideje su obično jednostavne ideje. U oblasti društvenih nauka, ideje koje utiču na milione ljude i usmeravaju nacionalne politike moraju biti dostupne svima, a ne samo elitama. Jedino na taj način mogu prožimati institucije od globalnog do lokalnog nivoa i postati deo ljudskih života. Model održivog razvoja predstavlja izazov konvencionalnoj formi razvoja. Naime, konvencionalni pristupi pojednostavljeno posmatraju razvoj kao globalnu modernizaciju prema uzoru na industrijalizovane, razvijene zemlje. Održivost je pozitivan imperativ koji spaja društvenu, ekonomsku i ekološku dobrobit, a ne proces balansiranja koji traži ravnopravne kompromise između inherentno konfliktnih sila. Ovaj rad obuhvata širok jaz između teorijskog tumačenja održivog razvoja $i$ aktuelnog stanja u svetu. Predstavljeni su pojedini kritički pogledi koji održivi razvoj posmatraju kao iluziju, ali i argumenti po kojima održivi razvoj nema alternativu.

Ključne reči: ekosistem, održivost, održivi razvoj, konvencionalni model. 